\title{
Interactive comment on "Error estimate for fluxgate magnetometer in-flight calibration on a spinning spacecraft" by Yasuhito Narita et al.
}

\author{
Yasuhito Narita et al. \\ yasuhito.narita@oeaw.ac.at \\ Received and published: 10 December 2020
}

We thank the both reviewers for their careful reading, thoughtful and useful comments, and their time for reading our manuscript. All the comments raised by the reviewers are well justified, and we worked on the revision along with replying to the reviewer comments. Deailed response to each of the reviewer comments and the revised manuscript are available in the attached pdf file.

Please also note the supplement to this comment:

https://gi.copernicus.org/preprints/gi-2020-31/gi-2020-31-AC1-supplement.pdf

Interactive comment on Geosci. Instrum. Method. Data Syst. Discuss., 
https://doi.org/10.5194/gi-2020-31, 2020.

\section{GID}

Interactive comment 